\title{
The EU's Convergence Dilemma
}

\section{Ton Notermans}

\author{
Department of International Relations, \\ Tallinn University of Technology \\ Akadeemia tee 3, \\ Tallinn 12618, Estonia \\ E-mail: antonius.notermans@ttu.ee
}

Abstract: As economic stagnation continues to mark the EU in the fifth year of the euro zone crisis, political support for integration is waning. The European Parliament elections of 2014 returned a hitherto unparalleled number of Eurosceptic MEPs, with EU-critical parties becoming the largest ones in several Member States. Much of this Euroscepticism is driven by economic polarisation between core and peripheral countries. While an increasing number of voters in the northwestern creditor countries resent having to foot the bill for what they consider economic mismanagement in the periphery, voters in peripheral countries increasingly rebel against what they deem to be an economically catastrophic Diktat from Germany and its allies. Continued political support for European integration will hinge on successful income convergence in the EU but the current dilemma is that such policies might not be politically feasible. Periods of rapid convergence would seem to suggest that success depends on two main policy strategies. First, a monetary policy that promotes credit for productive purposes, leaves inflation control to other instruments, and employs selective credit rationing to prevent asset booms. Second, a vertical industrial policy prioritising selected industrial sectors. The first policy conflicts with the present framework of euro zone monetary policy, but that framework was only installed in the first place because many peripheral countries were desperately in search of an external constraint on domestic distributional conflict. Industrial policies, in turn, require a sufficient degree of state autonomy from business elites in order to be effective, but it is highly questionable whether most states in the EU possess such autonomy. Though there are, as yet hesitant, signs of a reorientation 
of both monetary and cohesion policy in the EU, the question of the institutional and political preconditions for their successful implementation has been largely neglected.

Keywords: convergence, growth, investment and monetary policy, non-reciprocal integration

\section{Introduction}

More than four and a half years after the start of the euro crisis, it is difficult to discern any light at the end of the tunnel. The austerity policies aimed at reducing public debt and restoring investor confidence have instead intensified the crisis. With the sole exceptions of Latvia and Hungary, debt levels in all EU countries, but especially in those Member States that received financial assistance, are substantially higher than they were at the onset of the crisis in 2010. Gross Domestic Product (GDP) growth rates in the euro zone remain subdued and unemployment high, with Spain and Greece recording figures that had not been seen since the Great Depression of the 1930s. Despite a flurry of activities, the European banking system remains fragile, with a continued risk of financial bubbles (De Nederlandsche Bank, 2014, pp. 15-20). Unlike the USA, bank assets as a percentage of GDP have hardly been reduced in Europe with the result that bad debts are a continued source of potential instability.

However, the economically and politically most troublesome aspect of the European crisis is its uneven regional distribution. Though the massive private and public debts that had built up in peripheral countries since the introduction of the euro would not have accumulated if Northwest-European banks had not been more than willing to lend, the crisis was primarily framed as caused by irresponsible fiscal management in South-European countries, somewhat later followed by the additional narrative of failing national banking supervision in some countries. As the creditor countries successfully managed to unilaterally shift the blame to the debtor countries, the solution that the lending institutions should face the consequences of their failure to perform sufficient creditworthiness checks and be required to write off a significant part of their debts was not even contemplated. Placing the adjustment burden on the debtors, however, had the consequence that what the World Bank (Gill \& Raiser, 2012) has termed the world's most successful convergence machine has switched into reverse. In terms of per capita GDP, all South-European countries have lost ground relative to Germany, whereas most East-European countries seem to be 
stuck in a middle income trap with the current crisis undoing much of the gains made during the preceding boom.

On the heels of the economic polarisation of the EU follows a political polarisation. An increasing number of Northwest-European countries has to contend with Eurosceptical parties whose popularity is in large part driven by the perception that domestic taxpayers are being made to pay for economic mismanagement in peripheral states. In a mirror image, many South-European countries now boost parties whose criticism of European integration rests on the belief that an economic Diktat, from Germany in particular, is ruining their prosperity. The most worrisome example in this respect may be the traditionally profoundly Europhile Italian electorate which returned an, albeit slight, majority to Eurocritical parties in the 2014 European Parliament elections.

There can be little doubt that the future of the EU will largely depend on its ability to restart the convergence machine. A flurry of reform initiatives in the field of economic governance notwithstanding, the EU's basic convergence approach seems to have changed very little since the crisis. In essence, its developmental models rest on a peculiar mix of liberalism and interventionism. The emphasis on completion of the single market as an engine of growth would seem to betray a liberal lineage as it not only assumes that a single market will allow for the exploitation of economies of scale, but, more importantly, that it will improve market efficiency through increased competition and a reduction of market distorting national policies. Of a similar liberal provenance is the 'conservative central banker model' (Svensson, 1995) that underpins its macroeconomic orientation. According to this view, governments face an incentive to boost the economy by means of monetary and fiscal expansion but since the level of economic activity is determined by the structural efficiency of the market, this policy will fail in the longer run but at the price of higher inflation. Accordingly, a monetary policy informed by the goal of keeping inflation low, and backed up by balanced-budget fiscal policies removes destabilising policy shocks, thus providing the optimal background for convergence. Yet, in other policy areas, the EU displays a less pronounced confidence in markets. From modest beginnings, EU structural policies have risen to the second largest expenditure item. The understanding is that market-based convergence must be complemented by intervention in the form of spending on infrastructure, education, innovation and other measures apt to improve economic efficiency. Moreover, the EU recently has come to emphasise the need for an industrial policy (EC, 2014); the latter term being considered a swear word in the liberal vocabulary.

The experience of the most successful cases of convergence such as Western Europe and a host of East-Asian economies after 1945, however, makes it appear 
doubtful that relatively minor adjustments to the current model will jump-start the convergence machine. These successful cases differed in two crucial respects from the current European model. Firstly, as Section 3 argues, on the basis of a conservative banker model, rapid convergence seems impossible. The essence of convergence is a high rate of investment and since bank credit commonly provides the main financing source this requires a monetary policy promoting credit creation, assisted by selective credit allocation to ensure that credit flows to productive uses instead of asset speculation, as well as an ability to rely on nonmonetary instruments for containing inflation. Igniting the European convergence machine hence would require cleaning up the bad debts in the financial system so as to restore the willingness to lend, and a switch to a monetary poly-regime which refuses to curtail growth for the sake of subduing inflation. The first measure currently seems politically impossible, whereas the second policy would require that viable non-monetary instruments for inflation control are available.

Secondly, Section 4 argues that on the microeconomic side, successful convergence is characterised by a heavy reliance on vertical, selective industrial policies as compared to the horizontal measures emphasised in the EU's cohesion policy (Amsden, 2007; Chang, 2003; Lin, 2012; Lin \& Chang, 2009; Lin \& Monga, 2013; Stiglitz, 1996). Given the highly divergent levels of development between the 28 members, vertical industrial policies will need to practice a form of positive discrimination in favour of the less developed regions and thus come into conflict with the level-playing field principle that undergirds the common market. The EU does not seem willing to make this departure, but more importantly, it is by no means clear that the political preconditions for the successful pursuit of such policies currently exist in Europe. It is essential that the state enjoy a sufficient degree of autonomy that prevents selective intervention from degenerating into clientelistic support of permanently uncompetitive firms (Evans, 1995; Kohli, 2004). Yet, research on state structures would suggest that many of the Member States most in need of such policies do not possess such autonomy (Innes, 2014).

While the euro crisis has sparked an intense and much-needed debate on the reform of economic governance in Europe, its orientation remains overly narrow in the sense that it focusses primarily on the pros and cons of alternative policies, while largely ignoring the issue of the political preconditions for the successful pursuit of such policies. The concluding section thus speculates a bit on whether and how the EU could play a useful role in this respect. First, however, the next section attempts to show that convergence performance in the EU has been rather disappointing. 


\section{Convergence in Europe and East Asia}

Post-Second World War Europe, has seen two clear instances of successful convergence: the rapid catch-up to American levels of the war-ravaged WestEuropean economies in the first three decades after 1945, and Ireland from the late 1980 s to 2007 . Though generally expecting that a short-lived post-war boom would soon give way to a recession, just as had happened after the First World War, the boom would not peter out until sometime in the 1970s and early 1980s, during which time much of the GDP per capita gap with the USA was closed. Admittedly, Western Europe never entirely reached the level of the USA and since the 1980s catch-up visibly slowed down or even halted. Yet, most of the gap was due to West-European economies providing fewer jobs and shorter working hours. Output per hour worked in many countries was roughly equal to, or even exceeded the US level (Eichengreen, 2006, pp. 379ff). Ireland, which joined the EEC in 1973, made rapid progress since the late 1980s, significantly surpassing Germany's per capita GDP in 2007, the last year before the crisis. However, since then it has rapidly lost ground.

Table 1 looks at convergence towards the level of Germany, which is generally considered Europe's most competitive, albeit not its richest, economy. The Table uses EKS data instead of the GK data employed by Gill and Raiser because the GK method overstates the income levels of poorer countries (Ackland, Dowrick $\&$ Freyens, 2013). As emerges from Table 1, the favourable performance of Western Europe and Ireland was not repeated by the Southern and Eastern members that joined after the 1970s. Most of the catch-up in Greece, which joined in 1981, took place before 1980, and indeed its position relative to Germany in 2013 is worse than it was in 1980. Portugal and Spain joined in 1986 and show a somewhat similar picture. By 2013, both countries had hardly made any progress relative to 1980. Cyprus became an EU member only in 2004 and there is no sign that it has benefited from a European convergence machine. Instead, by 2013 its position had deteriorated significantly from premembership years. Italy finally differs from the other southern EU states, as it is a founding member, and has a much stronger economic structure, mainly due to a large number of highly competitive SMEs in the northern part of the country. Also here most progress was booked between the 1950s and 1990s with its relative position deteriorating since then.

In Eastern Europe and the Baltics, the overall picture is one of relative stagnation since the collapse of communism, suggesting that most of them may have become stuck in a middle income trap. Only Poland, Estonia and the Slovak Republic 
Table 1: PPP per capita GDP relative to Germany in 2013 EKS dollars (\%), EU and East Asia

\begin{tabular}{|c|c|c|c|c|c|c|c|}
\hline \multicolumn{8}{|c|}{ Euro Zone Financial Assistance Countries } \\
\hline & 1960 & 1970 & 1980 & 1990 & 2000 & 2007 & 2013 \\
\hline Cyprus & 26.3 & 37.9 & 41.9 & 57.4 & 61.7 & 62.9 & 49.9 \\
\hline Greece & 47.4 & 64.9 & 72.3 & 67.2 & 69.4 & 82.7 & 59.6 \\
\hline Ireland & 53.4 & 53.7 & 57.0 & 65.7 & 105.1 & 115.9 & 95.2 \\
\hline Italy & 78.0 & 89.0 & 92.8 & 95.9 & 94.3 & 90.5 & 76.8 \\
\hline Portugal & 36.2 & 46.6 & 52.8 & 59.2 & 65.0 & 62.0 & 53.4 \\
\hline Spain & 44.2 & 63.1 & 70.8 & 77.2 & 84.4 & 86.9 & 73.8 \\
\hline \multicolumn{8}{|l|}{ Baltic Republics } \\
\hline & 1960 & 1970 & 1980 & 1990 & 2000 & 2007 & 2013 \\
\hline Estonia & -- & -- & 35.4 & 33.8 & 33.7 & 53.5 & 51.3 \\
\hline Latvia & -- & -- & 41.3 & 39.6 & 26.4 & 45.6 & 40.7 \\
\hline Lithuania & -- & -- & 51.2 & 46.3 & 29.6 & 47.2 & 46.0 \\
\hline \multicolumn{8}{|l|}{ Eastern EU } \\
\hline & 1960 & 1970 & 1980 & 1990 & 2000 & 2007 & 2013 \\
\hline Bulgaria & 29.8 & 34.0 & 33.1 & 25.6 & 22.0 & 31.6 & 32.6 \\
\hline Czech Republic & -- & -- & -- & 61.2 & 55.3 & 69.7 & 67.3 \\
\hline Hungary & 62.4 & 59.7 & 57.7 & 49.2 & 44.1 & 51.6 & 46.9 \\
\hline Poland & 43.8 & 41.9 & 41.9 & 31.1 & 38.0 & 45.6 & 51.9 \\
\hline Romania & 32.5 & 34.9 & 39.0 & 27.6 & 20.5 & 28.6 & 28.7 \\
\hline Slovak Republic & -- & -- & -- & 42.2 & 40.8 & 55.8 & 58.2 \\
\hline Slovenia & -- & -- & 85.6 & 61.0 & 64.0 & 78.5 & 69.0 \\
\hline \multicolumn{8}{|c|}{ EU Core Countries } \\
\hline & 1960 & 1970 & 1980 & 1990 & 2000 & 2007 & 2013 \\
\hline Austria & 89.3 & 92.8 & 100.9 & 103.2 & 109.4 & 114.7 & 112.3 \\
\hline Belgium & 90.9 & 96.3 & 101.2 & 100.2 & 103.6 & 106.1 & 102.1 \\
\hline Denmark & 109.8 & 109.8 & 101.6 & 102.5 & 109.0 & 107.9 & 96.8 \\
\hline Finland & 76.0 & 81.1 & 84.5 & 91.7 & 92.7 & 103.9 & 94.8 \\
\hline France & 91.7 & 98.2 & 97.9 & 97.4 & 96.2 & 95.0 & 87.7 \\
\hline Netherlands & 112.1 & 112.4 & 106.4 & 104.0 & 114.1 & 115.6 & 105.3 \\
\hline Sweden & 111.3 & 114.4 & 101.8 & 99.9 & 101.2 & 111.6 & 111.0 \\
\hline United Kingdom & 106.3 & 91.9 & 85.1 & 90.0 & 100.9 & 108.7 & 97.6 \\
\hline \multicolumn{8}{|c|}{ Japan and the Four Tigers } \\
\hline & 1960 & 1970 & 1980 & 1990 & 2000 & 2007 & 2013 \\
\hline Hong Kong & 35.0 & 44.2 & 62.9 & 85.7 & 91.8 & 111.3 & 119.6 \\
\hline Japan & 49.9 & 84.5 & 90.0 & 104.9 & 97.6 & 96.9 & 93.3 \\
\hline Singapore & 34.9 & 46.6 & 73.2 & 95.7 & 122.3 & 139.8 & 149.5 \\
\hline South Korea & 13.2 & 16.2 & 23.7 & 41.8 & 61.6 & 74.7 & 83.0 \\
\hline Taiwan & 16.4 & 21.3 & 34.0 & 53.6 & 76.6 & 89.7 & 98.6 \\
\hline
\end{tabular}

Source: The Conference Board, Total Economy Database, author's calculations. 
have made notable progress since 1990. With the exception of Bulgaria and Romania, who joined in 2007, the remaining states became EU members in 2004. Again, there are few signs of a convergence machine operating. In fact, with the exception of Poland and the Slovak Republic, all of them have lost ground relative to Germany since 2007.

The bottom panel of Table 1 finally looks at the convergence performance of Japan and the so-called 'Four Tigers' since 1960. Gill and Raiser's (2012, pp. 4, 74) claim that Europe has a far better claim to the title of the most successful 'convergence machine' than East Asia would not seem to bear scrutiny. In 1960, the relative per capita GDP was at or below the East and Southern European level, whereas by 2013 these countries had caught up or surpassed the EU's core states. However, compared to Western Europe their hourly output remains relatively low, ${ }^{1}$ meaning that their high per capita GDP is due to these economies providing more labour (longer working hours) to more people (lower unemployment rates).

In sum, if there ever was a convergence machine in Europe, it operated in Western Europe before the 1980s and in Ireland between the late 1980s and 2007. Convergence visibly slowed down at around the time when the EU started to transform from a free trade zone for manufactured goods plus agricultural protectionism into a much more encompassing arrangement in the 1980s. As a result, the poorer Member States that have joined since then have experienced relative stagnation, with clear tendencies towards divergence since 2008. The most impressive convergence machine has operated in East Asia, and Gill and Raiser notwithstanding, there would seem to be good reasons to rethink the European developmental model in the light of those success.

\section{Growth, investment and monetary policy}

Convergence is generally considered a microeconomic issue of innovation and productivity. Accordingly, the post-1945 catch-up is seen to have occurred because Western Europe was well inside the technology frontier, while the post-1980 slowdown resulted because it is easier to catch up than to innovate (Eichengreen, 2006). However, such an interpretation cannot explain why the EU's periphery consistently lags behind. Moreover, an exclusive focus on microeconomic factors is only justified when all factors of production are

1 Based on EK output per hour according to The Conference Board, Total Economy Database. 
fully utilised, which most obviously is not so, given Europe's horrendous unemployment. Finally, as new technology enters the production process though investment, productivity itself is influenced by macroeconomic forces.

Catch-up per definition implies a rapid increase of the physical capital employed in the economy. While the neoclassical textbook sees investment as determined by savings, since Wicksell at the latest, we know that savings only constitute the budget constraint in a pure cash economy. In a modern-day credit economy, the commercial banks, together with the central banks are the main source of credit creation (Arnon, 2011, Ch. 17; Wicksell, [1935]1978). As a result, the causality runs from credit to investment to savings as only credit will create the purchasing power out of which can be saved.

Indeed, what all cases of successful development have in common is a high rate of gross fixed capital formation (GFCF) for productive purposes (Rodrik, 1995; Teranishi \& Sachs, 1994). Tight control of the commercial banking system coupled with a policy of forced credit expansion provided the financing for such investment. One of the first acts of Park Chung Hee, when he assumed power in Korea in 1961, was to nationalise the banking system, in order to be able to direct sufficient credit to priority industrial sectors. While not having been nationalised, the Bank of Japan (BoJ) similarly kept a tight reign over commercial banks until well into the 1980s through the so-called window guidance (Werner, 2005, Ch. 20). With the exception of the City of London, the financial sector in Western European countries was shielded from foreign competition and subjected to detailed regulation and intervention. As in many East-Asian countries, selective credit rationing and allocation was widely employed to direct credit to priority sectors, whereas monetary policies focussed on keeping interest rates low. ${ }^{2}$

Apart from a possible foreign currency constraint, which may be solved through aggressive export promotion (Fukumoto \& Muto, 2011; Rodrik, 1995) the main limitation of such a strategy is that it lacks an instrument for containing inflation. Rapid growth inevitably coincides with some inflation. At eight per cent, average inflation rates in post-war Asia were considerably higher than the two per cent the European Central Bank (ECB) would currently tolerate (World Bank, 1993, pp. 106-107). However, high and escalating inflation clearly has a negative effect on productive activity (Riese, 1986), so that the tolerance of the Central Bank should not be too pronounced.

In Europe, the Great Inflation of the 1970s eventually terminated this growth

2 E.g., Jäntti and Vartiainen (2009) point to the fundamental similarities between the post-war Finnish and Korean catch-up strategies. 
model. Containing inflation under a monetary policy dedicated to prompting investment, essentially boils down to tripartite negotiated incomes policies. Because such policies are more easily implemented in centralised wage bargaining systems and under cooperative relations between the labour market parties and the government, the northwestern European countries had an institutional advantage in this respect relative to the generally more fragmented and conflictual political systems and labour relations in Southern Europe. In southern Europe, the solution to this dilemma eventually was to import an external constraint of tight money via EMS and subsequently euro zone membership (Notermans, 2012). Despite being institutionally and politically better placed, Northwest-European countries such as Germany, the Benelux countries, Austria, Sweden, and Denmark eventually also embraced the conservative central banker model, which argued that tight money had no longer-term negative effects on growth. Institutionally the attempt to pursue wage moderation put trade union leaderships in the unenviable position of continuously having to advocate moderation while the side payments required for such bargains to hold were increasingly undermining the fiscal autonomy of the government. The more attractive solution seemed an export-driven growth strategy in a European fixed exchange rate arrangement, which would allow these countries to exploit their greater institutional ability for wage moderation, in combination with a monetary policy that focussed solely of inflation and thus freed both unions and the state from the shackles of tripartite bargaining.

It was this change in monetary policy regime that stood behind the growth slowdown in Europe since the 1980s. It did so directly by the level of economic activity whenever inflation targets seemed threatened (Martin, 2004). But more important were its effects on growth expectations. By announcing an inflation target, the central banks effectively provided a focal point for the necessarily reflexive growth expectations of lenders and borrowers.

Yet this new regime was to sow the seeds of its own demise. Exclusively focussed on consumer price inflation, it could be counted on not to put a damper on asset price speculation while simultaneously discouraging "productive" investment. Whereas the tight control on commercial banks that had characterised the Trente Glorieuses did much to prevent asset bubbles, under the new monetary regime such constraints not only appeared unnecessary, but a check on the growth of a promising sector. With the emphasis an external monetary constraints providing domestic discipline, also the existing cross-border capital controls in the EU seemed rather counterproductive and were eventually abolished by 1994 (EU, 1998). 
The result was a catastrophic build-up of European imbalances as NorthwestEuropean banks funnelled massive amounts to real estate speculation, sovereign debt and consumption booms on the periphery (Jacoby, 2014). The reduction of risk premia after the introduction of a common currency provoked massive capital inflows to the southern periphery, with the exception of Italy. Much the same process could be observed in the Eastern European countries that adopted a hard peg and were identified as future EU members (Stark, 2009, pp. 2223). The result was that for a brief period between the late 1990s and 2007 the EU did indeed seem a convergence machine. Whereas some countries in close proximity to Germany like Hungary and the Czech and Slovak republics did substantially benefit from FDI in manufacturing, much of the funds flowing to the periphery turned out to be a poisoned chalice.

Since the bubble has finally also burst in Europe with the onset of the euro crisis in May 2010, the ECB has de facto come to abandon the conservative central banker model that has guided monetary policies in Europe since the 1980. Instead of arguing that higher investment will require more saving and that monetary expansion will only be inflationary, the ECB is flooding the commercial banks with liquidity in order to prevent their collapse though the so-called long-term refinancing operation. Since September 2013, moreover, the ECB has extended an unlimited guarantee of the sovereign debt of the countries under EFSF assistance in order to prevent a cumulative spiral of reduced confidence, higher interest spreads and increased debt burdens. Finally, in the fall of 2014, the ECB is preparing to engage in quantitative easing so as to directly provide credit to the real economy, something the commercial banks apparently are very reluctant to do.

As such, this scuttling of old doctrines and the rediscovery of the fact that bank credit and investment stand at the core of growth is more than welcome. However, just as the BoJ, after the asset bubble burst in the early 1990s, the ECB is finding out that it is hard to push on a string. With massive amounts of bad debt in the system, deleveraging became the first corporate priority in Japan such that neither massive spending programmes, in the wake of which public debt rose to over 200 per cent of GDP, nor a zero interest rate policy did much to rekindle growth (Koo, 2008). Yet, apart from the modest Greek "haircut" in 2012, the ECB has been fiercely opposed to any form of (partial) debt default. As a result, the EU has made much less progress than the USA in downsizing a hypertrophic financial sector. In December 2013, the total assets/liabilities of euro zone's monetary and financial institutions amounted to 257 per cent of euro zone GDP. Despite the alleged restructuring of the financial sector, this is slightly higher than the December 2007 figure of 247 per cent (based on data from ECB, AMECO, and author's calculations). 
In this situation, a combination of devaluation and default would economically seem the best solution for the over-indebted European periphery. Reintroduction of a national currency and devaluation could immediately undo the loss of competitiveness suffered as a result of continuous real appreciation under the euro and could thus turn around the necessarily pessimistic expectations of industry. Debt restructuring, or outright default, in turn, would seem necessary to restart the lending process. Yet, politically such a solution would only be viable to the extent that the distributional struggles that caused the Great Inflation of the 1970s and necessitated an external constraint in the first place in SouthEuropean countries can be assumed to be a thing of the past.

\section{Non-reciprocal integration and the EU's level playing field}

The EU's model of development captures an essential driver of convergence, as it is hard to conceive how smaller nations could ever hope to prosper without access to foreign markets and technology. Where the EU's emphasis on a single market and a level playing field errs is that there is overwhelming evidence that development will not follow automatically from economic integration but requires substantial microeconomic intervention in the form of industrial, trade and technology (ITT) policies (Amsden, 2004; Breznitz, 2007; Chang, 2003).

Because long learning curves, economies of scale and coordination problems due to imperfect tradability of inputs commonly characterise complex manufacturing processes, first-mover advantages emerge that would cement the existing international division of labour unless checked by ITT policies on the part of less developed countries (Rodrik, 1995). Moreover, the potential contribution of foreign direct investment (FDI) will only be harvested if it is combined with arrangements that promote technology transfer to the host countries, such as joint ventures or local content rules. Otherwise, extensive foreign ownership in manufacturing risks promoting enclave economies with few backward and forwards linkages and limited spillovers (Ferry \& McMaster, 2013; Jacoby, 2010).

If, indeed, manufacturing is crucial to convergence, and Adam Smith (2007, p. 381) is right in that common sense "should make a whole nation regard the riches of its neighbours as a probable cause and occasion for itself to acquire riches", then development requires non-reciprocal international economic relations in which developed nations, in their own long-term economic and political interest, should tolerate discriminatory ITT practices. The cold war 
provided such a rare constellation. The original US blueprint for the post-war economic order envisaged fixed exchange rates, free trade and current account convertibility. Yet soon promoting the economic development of its allies to halt the advance of communism became the new priority. Amsden (2007, p. 40) succinctly summarised the new approach in four words, "Washington let 'reciprocity' slip."

Post-war Western Europe took extensive advantage of this opportunity. Currencies remained inconvertible until late December 1958, which de facto meant that most international trade was state controlled and frequently discriminated against the dollar area. In 1949, most West-European currencies devalued substantially relative to the dollar. In 1958, the EEC customs union was founded, which in itself discriminated against non-members while trade liberalisation between the six was stepwise, with transition periods of up to ten years, and applied only to trade in goods. The widely practised financial repression was part and parcel of a more encompassing industrial policy, especially in countries such as Italy, France and Belgium that were acutely aware of their relative backwardness.

The model of integration that gradually developed in the EU since the 1980s left much less leeway in this respect for new members. The Single European Act, implemented between 1986 and 1992, removed much of the remaining nontariff barriers and competition policy now became an exclusive EU competence. Although already included in the Rome treaties, competition policy remained a paper tiger as long as the creation of "national champions" was a core element in the catch-up strategies of countries such as France and Italy. The application of competition policy to state aid equally remained a dead letter, but since the 1980 s, state aid has also come under the provision of the EU. Although here the powers of the EU are considerably weaker than in the other fields of competition policy (Wilks, 2005, p. 123), crucial elements of "financial repression" such as "preferential interest rates and favourable loan terms" are now considered inadmissible (Rutkiewicz, 2011, p. 45).

The EU's insistence on the free movement of capital meant that it became very difficult for the eastern Member States to protect their own firms with the result that much of the manufacturing sector and most of the financial sector was transferred into foreign hands, while technology transfer frequently remained modest (Jacoby, 2010, p. 425).

This emphasis on reciprocal integration is somewhat tempered by the EU's cohesion policies which are specifically targeted at its less developed regions. Like the development aid that accompanies Europe's essentially liberal 
approach to less developed non-members, also the record of cohesion policies is rather discouraging. Indeed the finding that the industrial structure of the major recipients of regional aid, Spain, Portugal and Greece, suffers from serious problems that have intensified since the introduction of the euro (Simonazzi, Ginsburg \& Nocella, 2013) testifies to the inefficiency of these policies. This failure partly reflects inefficient management and pork-barrel politics (Bloom \& Petrova, 2013; ZEW, 2012). More importantly, perhaps, the emphasis of cohesion policies on horizontal aid such as education, infrastructure and entrepreneurship does not square with the classic developmental state strategies of channelling vertical aid to priority sectors. In addition, since the effect of horizontal aid is indirect, the EU does not apply the strict performance standards that proved so crucial in Asia to assure policy effectiveness.

Also on the microeconomic side, the crisis has set in train a policy reorientation in the EU. Rules on state aid to industry have been considerably relaxed though most of this concerns bail outs of the financial sector. In 2008-2010 alone, the Commission approved a staggering 3485.25 billion euros of state aid to the financial sector (Czekus, 2012, p. 330). The apparent structural weakness of many peripheral countries, in turn, has sparked a rediscovery of industrial policy at the EU Commission, a few years after a similar reorientation had occurred at the World Bank. Yet, it is too early to tell whether this new emphasis on vertical (sectoral) as opposed to horizontal aid constitutes a new departure (EC, 2014). The emphasis of the EU's new strategy remains on completion of the single market and a level playing field, with no recognition that the large disparities of development levels within the EU may call for forms of nonreciprocal integration. Channelling cohesion funds to targeted sectors on an EUwide basis, however, is more likely to cement the current division of labour in which especially Eastern Europe is assigned the low-tech low-wage activities in international production chains run by West-European companies.

Yet, the alternative of peripheral countries acquiring more policy autonomy versus Brussels so as to pursue an East-Asian style of ITT and policies aimed at creating competitors rather than low wage subcontractors to Western firms may well not be viable either. Firstly, the experience of Soviet rule served to discredit a more interventionist style of policy-making. Secondly, as has been stressed by a large number of studies of convergence strategies (Evans, 1995; Kohli, 2004; Rodrik, 1995), the insulation of governments from domestic interest groups was crucial in order to prevent rampant rent seeking. Democratic shock therapy in Eastern Europe, however, has resulted in the creation of many states that lack this autonomy. Putting newly formed parties with little or no roots in society in charge of state-building created enormous incentives to design the 
new institutions in such a way that governments could prey on them (GryzmalaBusse, 2007). Pervasive corporate capture of the state thus has become a feature of a substantial number of states (Innes, 2014). Similar problems have been widely documented for South-European countries, such as, for example, Greece (Mitsopoulos \& Pelagidis, 2011).

\section{From macro- to microeconomic constraints?}

Europe's core dilemma is that in order to prevent economic polarisation from undermining the political support for the EU, a form of non-reciprocal integration would be required that not only runs counter to a deeply held belief in the optimality of reciprocal integration, but that also may defy effective implementation. Reasonable doubt about the ability of many peripheral members to successfully implement an East-Asian convergence strategy imply that retuning policy autonomy to the Member States in the field of monetary and industrial policy may not be a promising road to take. However, the alternative of strengthening the reciprocal integration that has catheterised the EU since the 1980s is turning out to be a dead end (Laski \& Römisch, 2004, p. 240). Instead, what may be required is a stronger emphasis on differential integration with strengthened centralised oversight.

In the field of cohesion policy, the principle that differential levels of development justify different treatment is already entrenched. With the recognition that more vertical as opposed to horizontal aid is called for, the EU is in the process of taking a second hurdle. That such vertical aid should be targeted on a regional and national instead of EU-wide basis to prevent the cementing of a low-wage low-tech periphery versus a high-wage core may be a hurdle that can be taken in the near future in view of the mounting political and economic costs of a languishing periphery; somewhat similar to the revision of post-war American plans for the reconstruction of the international economy in view of the emerging cold war. Lack of the state autonomy required to successfully implement such programmes, in turn, would suggest that such programmes be based on the clear performance targets and deadlines that characterised the Korean and Japanese counterparts, and be removed from the established power structures of the countries concerned. The challenge here is to design a European agency immune to capture by local interests (see also Pitelis, 2014).

In terms of financial regulation, the boom and bust cycles to which many peripheral countries were subjected as a result of the introduction of the 
common currency, the removal of capital controls and the promotion of a single market in financial services would seem to confirm Bhagwati's (1998) insight that, in order to draw the benefits of integrated markets for goods and services, financial markets should be compartmentalised and fragmented. The ongoing construction of a banking Union instead moves in the opposite direction as the harmonisation of regulatory and supervisory practices may further promoting herding and instability (Wagner, 2012), while it is by no means clear that the ECB will be less prone to regulatory capture than national supervisors in several EU states have proven to be. In principle, the newly introduced excessive imbalances procedure (EIP) may serve to prevent the cross-border accumulation of liabilities that proved so damaging to the periphery. However, in its current form the EIP lacks bite. The challenge here is to design a clear trigger as well as symmetric enforcement instruments that recognise that burgeoning current account surpluses are as much of a problem as deficits.

Europe faces its most daunting challenges in the field of monetary management. The attempt to harmonise nominal unit labour costs by means of imposing an immutable nominal exchange rate constraint on countries with vastly different labour market institutions has clearly failed, as witnessed by the continuous real appreciation peripheral countries have suffered since the adoption of the euro. That would suggest the solution of a devaluation to restore competitiveness and halt the ongoing destruction of physical and human capital as well as the replacement of a system of nominal exchange rate rigidity with a system of nominal flexibility designed to safeguard real exchange rate stability. SouthEuropean countries with a long-standing reputation of devaluation-wage spirals strenuously resist devaluation for fear of creating a currency bereft of any credibility. With untested democratic systems and often weak and fragmented civil societies, most eastern members preferred never to run an autonomous monetary policy in the first place, but to buy credibility through hard pegs, currency boards and the ERM2. In short, the dilemma here is that the nominal rigidity of the euro destroys the real economy via real appreciation whereas a flexible currency might do so over escalating inflation and budget deficits once the constraints are removed. A monetary system targeting real exchange rate stability instead would accommodate such wage-price spirals unless combined with an incomes policy. Replacing the macroeconomic constraint of a common currency with the microeconomic one of an EU-led incomes policy, however, would seem unworkable. Whereas as sectorial industrial policy under EU aegis might be able to count on political support, EU-run wage policies would rather serve to fuel more opposition to integration in the periphery. 
This issue, however, is rapidly becoming a non-problem. As the EU reacted to the over-indebtedness of the periphery by an emphasis on austerity and reforms to increase labour market flexibility, the ECB is now facing a problem of deflation. In the conservative banker model that provides the official ECB view, deflation is a non-problem as the price level is under the control of the monetary authorities, while wage flexibility only affects relative prices. But the ability of any central bank to control the price level is asymmetrical. It stands in its power to halt inflation but it does so by depressing the economy and thus reducing labour market pressures. In an environment of high unemployment, falling nominal wages and subdued credit creation, instead, the ECB rapidly finds out that it lacks effective tools against deflation. As deflation is becoming the dominant fear, the emphasis on more labour market flexibility to solve the problems of the periphery, will sooner or later have to be abandoned in favour of nominal wage stabilisation. Though its favourite model has officially not been scuttled, under the force of circumstances the ECB de facto is gradually moving to the more realistic approach that nominal wages are the anchor of the price system. It is a quite significant departure that, in July 2014, the president and chief economist of the Bundesbank, supported by the chief economist of the ECB, called for higher wage increases in Germany to avert deflation (Reuters, 2014; Der Spiegel, 2014). Though still calling for more flexibility in the periphery, the ECB's latest labour market analysis (ECB, 2014) places more emphasis on promoting labour mobility throughout Europe; something which makes sense if the massive unemployment in Southern Europe is seen to be driving deflation.

Deflation will most likely also spell an end to austerity. As Wicksell pointed out, deflation may easily become cumulative as the bankruptcies caused by austerity and crushing debt will swell the ranks of the unemployed and further push wages down, while the expectation of deflation creates an incentive to hoard money, thus reducing aggregate demand. Also here the ECB, with support from the Commission, is now advocating more deficit-spending programmes, possibly by using part of the European Financial Stability Facility funds. Finally, as deflation takes hold and the real debt burden increases accordingly, also the debt default required to enable Europe's periphery to recover may become acceptable.

In a continent whose strength lies in its diversity, reciprocal integration is rapidly proving a dead end. While the EU recognises the need for a differential approach in cohesion policy, the insistence that any step back from reciprocal integration in money and finance, in combination with a concern to save the banks rather than its citizens (Underhill, 2012, p. 150) is overwhelming any positive contribution to be expected from industrial policies. The solution to the 
Great Depression of the $20^{\text {th }}$ century consisted of abandoning the Gold Standard in favour of devaluation and default, but this policy came too late to prevent the catastrophe of Nazi rule in Germany. It is to be hoped that the EU will muster sufficient flexibility in what rapidly is becoming the Great Depression of the $21^{\text {st }}$ century, to prevent another political catastrophe.

Ton Notermans, PhD has studied political science at the University of Amsterdam, the Freie Universität Berlin and MIT. He is currently associate professor of European Politics at the Department of International Relations, School of Economics and Business Administration, Tallinn University of Technology. Before coming to Tallinn, he was director of studies of the School of International Studies of the University of Trento (Italy).

\section{References}

Ackland, R.; Dowrick S. \& Freyens B. (2013), 'Measuring Global Poverty: Why PPP Methods Matter,' The Review of Economics and Statistics, vol. 95, no. 3, pp. 813-824. http://dx.doi.org/10.1162/REST_a_00294

Amsden, A. H. (2004), The Rise of the Rest, Oxford: Oxford University Press. (2007), Escape from Empire, Cambridge, MA: The MIT Press.

Arnon, A. (2011), Monetary Theory and Policy from Hume and Smith to Wicksell, Cambridge: Cambridge University Press.

Bhagwati, J. (1998), 'The Capital Myth: The Difference between Trade in Widgets and Dollars,' Foreign Affairs, vol. 77, no. 3, pp. 7-12.

http://dx.doi.org/10.2307/20048871

Bloom, S. \& Petrova, V. (2013), "National Subversion of Supranational Goals: 'PorkBarrel' Politics and EU Regional Aid," Europe-Asia Studies, vol. 65, no. 8, pp. 1599-1620. http://dx.doi.org/10.1080/09668136.2013.833014

Breznitz, D. (2007), Innovation and the State, New Haven: Yale University Press. http://dx.doi.org/10.12987/yale/9780300120189.001.0001

Chang, H.-J. (2003), Kicking Away the Ladder, London: Anthem Press.

Czekus, A. (2012), Responses of European Competition Policy to the Challenges of the Global Economic Crisis. Retrieved from http://mpra.ub.uni-muenchen.de/40360/ [accessed Nov 2014]

De Nederlandsche Bank (2014), Overzicht Financiële Stabiliteit: Najaar 2014, Amsterdam: De Nederlandsche Bank

Der Spiegel (2014), 'Bundesbank für höhere Lohnabschlüsse,' 20 July 2014. Retrieved from http://www.spiegel.de/spiegel/vorab/bundesbank-fuer-hoeherelohnabschluesse-a-981911.html [accessed Nov 2014] 
EC (2014), Communication from the Commission to the European Parliament, the Council, the European Economic and Social Committee and the Committee of the Regions: For a European Industrial Renaissance, COM(2014) 14 final, Brussels: European Commission.

ECB (2014), 'The Impact of the Economic Crisis on EURO Area Labour Markets,' ECB Monthly Bulletin, October, pp. 49-68.

Eichengreen, B. (2006), The European Economy Since 1945, Princeton, NJ: Princeton University Press.

EU (1998), Achieving the free circulation of capital, Council Directive 361/1988, 24.06.1988.

Evans, P. B. (1995), Embedded Autonomy, Princeton, NJ: Princeton University Press.

Ferry, M. \& McMaster, I. (2013), 'Between Growth and Cohesion: New Directions in Central and East European Regional Policy,' Europe-Asia Studies, vol. 65, no. 8, pp. 1499-1501. http://dx.doi.org/10.1080/09668136.2013.832958

Fukumoto, T. \& Muto, I. (2011), "Rebalancing China's Economic Growth: Some Insights from Japan's Experience," Bank of Japan Working Paper Series, No. 11E-5, July.

Gill, I. S. \& Raiser, M. (2012), Golden Growth: Restoring the Lustre of the European Economic Model, Washington, DC: International Bank for Reconstruction and Development.

Grzymala-Busse, A. (2007), Rebuilding Leviathan, Cambridge: Cambridge University Press. http://dx.doi.org/10.1017/CBO9780511618819

Innes, A. (2014), 'The Political Economy of State Capture in Central Europe,' Journal of Common Market Studies, vol. 52, no. 1, pp. 88-104. http://dx.doi.org/10.1111/ jcms. 12079

Jacoby, W. (2010), “Managing Globalization by Managing Central and Eastern Europe: the EU's Backyard as Threat and Opportunity," Journal of European Public Policy, vol. 17, no. 3, pp. 416-432. http://dx.doi.org/10.1080/13501761003661935

(2014), 'The EU Factor in Fat Times and in Lean: Did the EU Amplify the Boom and Soften the Bust?' Journal of Common Market Studies, vol. 52, no. 1, pp. 52-70. http://dx.doi.org/10.1111/jcms. 12076

Jäntti, M. \& Vartiainen J. (2009), 'The Finnish Developmental State and its Growth Regime,' UNU-WIDER Research Paper No. 2009/35, Helsinki: UNU-WIDER.

Kohli, A. (2004), State-Directed Development, Cambridge: Cambridge University Press. http://dx.doi.org/10.1017/CBO9780511754371

Koo, R. C. (2008), The Holy Grail of Macroeconomics, Singapore: John Wiley \& Sons.

Laski, K. \& Römisch, R. (2004), 'Lessons to be Learnt from Earlier Accessions,' in M. A. Landesmann \& D. K. Rosati (eds.) Shaping the New Europe Economic Policy Challenges of European Union Enlargement, London: Palgrave Macmillan. 
Lin, J. \& Chang, H.-J. (2009), 'Should Industrial Policy in Developing Countries Conform to Comparative Advantage or Defy it? A Debate Between Justin Lin and Ha-Joon Chang,' Development Policy Review, vol. 27, no. 5, pp. 483-502. http://dx.doi.org/10.1111/j.1467-7679.2009.00456.x

Lin, J. Y. (2012), New Structural Economics: A Framework for Rethinking Development and Policy, Washington, DC: The World Bank.

Lin, J. Y. \& Monga, C. (2013), 'Comparative Advantage: The Silver Bullet of Industrial Policy,' in J. E. Stiglitz \& J. Y. Lin (eds.) The Industrial Policy Revolution: The Role of Government Beyond Ideology, New York: Palgrave Macmillan. http://dx.doi.org/10.1057/9781137335173.0008

Martin, A. (2004), 'The EMU Macroeconomic Policy Regime and the European Social Model,' in A. Martin \& G. Ross (eds.) Euros and Europeans: Monetary Integration and the European Model of Society, Cambridge: Cambridge University Press.

Mitsopoulos, M. \& Pelagidis, T. (2011), Understanding the Crisis in Greece: From Boom to Bust, New York: Palgrave Macmillan. http://dx.doi.org/10.1057/9780230294752

Notermans, T. (2012), 'Predatory Preferences and External Anchors: The Political Sources of European Imbalances,' Baltic Journal of European Studies, vol. 2, no. 2(12), pp. 8-20. http://dx.doi.org/10.11590/bjes.2012.2.01

Reuters (2014), 'ECB Backs Bundesbank Call for Higher German Wages - Der Spiegel,' 27 July 2014. Retrieved from http://uk.reuters.com/article/2014/07/27/uk-ecbgermany-wages-idUKKBNOFW0FE20140727 [accessed Nov 2014]

Riese, H. (1986), Theorie der Inflation, Tübingen: J. C. B. Mohr.

Rodrik, D. (1995), 'Getting Interventions Right: How South Korea and Taiwan Grew Rich,' Economic Policy, vol. 10, no. 20, pp. 53-107. http://dx.doi.org/10.2307/1344538

Rutkiewicz, K. (2011), 'State Aid in the European Union: Competition Policy in the Context of the Financial Crisis,' Equilibrium, vol. 6, no. 3, pp. 43-58.

Simonazzi, A.; Ginzburg, A. \& Nocella, G. (2013), 'Economic Relations between Germany and Southern Europe,' Cambridge Journal of Economics, vol. 37, pp. 653-675. http://dx.doi.org/10.1093/cje/bet010

Stark, J. (2009), 'Fast, but Sustainable? Challenges and Policy Options for the Catching-up Process of Central and Eastern European Countries,' in R. Martin \& A. Winkler (eds.) Real Convergence in Central, Eastern and South-Eastern Europe, New York: Palgrave Macmillan.

Stiglitz, J. (1996), 'Lessons from the East Asian Miracle,' The World Bank Research Observer, vol. 11, no. 2, pp. 151-177. http://dx.doi.org/10.1093/wbro/11.2.151

Svensson, L. E. O. (1995), “Optimal Inflation Target, 'Conservative' Central Banks, and Linear Inflation Contracts," NBER Working Paper 5251, Cambridge, MA: NBER. 
Teranishi, J. \& Sachs, J. (1994), "Economic Recovery, Growth and Policies: 'Gradualism' in the Japanese Context," Economic Policy supplement Lessons for Reform, vol. 9, no. 19, pp. 137-153.

Underhill, G. D. (2012), 'The Political Economy of (Eventual) Banking Union,' in T. Beck (ed.) Banking Union for Europe: Risks and Challenges, London: CEPR.

Wagner, W. (2012), 'How to Design a Banking Union that Limits Systemic Risk in the Eurozone?' in T. Beck (ed.) Banking Union for Europe: Risks and Challenges, London: CEPR.

Werner, R. A. (2005), New Paradigm in Macroeconomics, New York: Palgrave Macmillan.

Wicksell, K. ([1935]1978), Lectures on Political Economy. Volume Two: Money, Fairfield: Augustus M. Kelley Publishers.

Wilks, S. (2005), 'Competition Policy: Challenge and Reform,' in H. Wallace, W. Wallace \& M. Pollack (eds.) Policy Making in the European Union, $5^{\text {th }}$ edition, Oxford: Oxford University Press.

World Bank (1993), The East Asian Miracle: Economic Growth and Public Policy, Oxford: Oxford University Press.

ZEW (2012), Growth Enhancing Expenditure in EU Cohesion Spending from 2007 to 2013, Mannheim: Zentrum für Europäische Wirtschaftsforschung. 